\title{
Sin "cieno ni obscenidad": el censor de películas Francisco Ortiz Muñoz, inventor de su propio paraíso (1946)
}

\section{Julia Tuñón}

\section{(2) OpenEdition \\ Journals}

Edición electrónica

URL: http://journals.openedition.org/agedor/2727

DOI: 10.4000/agedor.2727

ISSN: 2104-3353

Editor

Laboratoire LISAA

Referencia electrónica

Julia Tuñón, «Sin "cieno ni obscenidad": el censor de películas Francisco Ortiz Muñoz, inventor de su propio paraíso (1946) », L'Âge d'or [En línea], 2 | 2009, Publicado el 08 marzo 2009, consultado el 19 septiembre 2019. URL : http://journals.openedition.org/agedor/2727 ; DOI : 10.4000/agedor.2727

Este documento fue generado automáticamente el 19 septiembre 2019.

L'Âge d'or. Images dans le monde ibérique et ibéricoaméricain 


\title{
Sin "cieno ni obscenidad": el censor de películas Francisco Ortiz Muñoz, inventor de su propio paraíso (1946)
}

\author{
Julia Tuñón
}

1 En el Madrid de posguerras Francisco Ortiz Muñoz, un censor empleado como tal por el Régimen, dicta una conferencia acerca de su oficio y como producto de ella se publica un pequeño texto: Criterios y normas morales de censura cinematográfica. Conferencia pronunciada en el Salón de Actos del Consejo Superior de Investigaciones Científicas el día 21 de junio de 19461. En estos años la censura está ya suficientemente impuesta para tener criterios establecidos, pues han pasado muchas películas bajo la mirada inquisidora de la Junta de Clasificación y Censura de Películas Cinematográficas ${ }^{2}$, lo que le da un estilo propio, aunque las normas no están explicitadas ni son claras: la primera codificación es de abril de $1963^{3}$. En los dictámenes sobre las películas, se observa bastante arbitrariedad y el hecho de que el carácter y los criterios personales de cada censor influyen en las decisiones, a veces se ventilan o discuten los argumentos pero a veces simplemente se impone alguna autoridad, el canon o la costumbre. En términos generales tienen tolerancia con la mala calidad de un film o la tontería de un guión, pero no con las delicadas cuestiones que atañen a la política, los conceptos sociales, el honor o la "moralidad" sexual. Cuando no hay argumentos claros; a menudo se recurre a la adjetivación, sobre todo cuando se trata de un rechazo visceral. Doménech Font habla de "baluartes adjetivados" como los conceptos de raza, triunfo, victoria, misión o espíritu nacional ${ }^{4}$. Pareciera que no hay un criterio uniforme, pero sí que, como explica el censor Francisco Ortiz Muñoz, hay ideas generales que se han aplicado sistemáticamente y conforman un código tácito, lo que le permite dictar su conferencia con gran seguridad.

2 Seguramente entre su audiencia circulaban incertidumbres de diverso carácter y el texto de Ortiz Muñoz puede haber aplacado algunas suspicacias, pues en general es coherente con las ideas que propugna y da una imagen clara de los principios aceptados en ese momento por la censura, aunque haya algunas contradicciones que marcaremos. 
Si acaso algunos pensaron que su Proyecto coartaba su libertad, no estaban en condiciones de expresarlo. Sabemos que al interior de la Junta había tensiones, que se pueden apreciar incluso en los expedientes de las películas censuradas ${ }^{5}$. Ortiz parece representar claramente una tendencia hegemónica en esos años, el llamado nacionalcatolicismo, pero no es exclusiva en la Junta, pues los militantes de Falange, por ejemplo, a pesar de estar en pleno declive, tenían sus propias opiniones respecto a cuestiones sociales; en los primeros años la influencia del ejército era también remarcable y la eclesiástica fue muy fuerte. Aquí nos centraremos en el proyecto de Ortiz Muñoz, aunque parezca claro que hay un pulso entre los censores, por un lado, pero también entre la Junta, el Estado y la Iglesia, con sus procesos particulares y, por otro lado, con la población en general que no podía expresarse pero tenía formas oblicuas de resistir. Es una arena de luchas múltiples que requiere de una negociación muy fina al interior y con el exterior, por lo que, como decía Ortiz Muñoz:

[...] debe intervenir la prudencia política, la cual manda o aconseja, según los casos, permitir o disimular ciertos males cuya prohibición traería consigo otros mayores. Pero nunca se ha de aprobar lo malo ni condenar lo bueno, ni de modo alguno dar a entender que el error es verdad y el vicio virtud o cuando menos no es vicio ${ }^{6}$.

3 La censura fílmica en España se establece por real Orden de 1912, con la intención de proteger a la juventud ante la influencia de un medio tan novedoso y ambiguo, cargado de "apariencias de realidad y visiones fantásticas, trágicas, terroríficas y perturbadoras"7 es decir, se trata de conjurar su efecto de realidad, una de sus características más remarcables y atractivas que aparece ya como uno de sus mayores peligros. Sin embargo cuando la censura adquiere un peso mayúsculo es con la victoria franquista, y se convierte en una de las herramientas medulares del régimen, entrando con precisión en el concepto poco citado en nuestros días de aparato ideológico del Estado $^{8}$. La censura fílmica que emerge del Movimiento Nacional ostenta enfáticamente el propósito de regular férreamente las películas que miran los españoles. Fue creada en 1936 en la Junta de Burgos, "naciendo en los campos de batalla"9 según decir de Román Gubern y para 1937 tiene ya un modelo de organización que durará hasta su disolución en 1977, aunque sufra modificaciones de variada índole ${ }^{10}$, de acuerdo a presiones y tensiones tanto internas como externas y a los cambios que viven España y el mundo. Ciertamente la censura modifica con el tiempo sus prioridades, en los primeros tiempos vigilando con lupa lo que pudiera referir a la política y después más y más al incremento de los frecuentes y desbordados contenidos sexuales. Ciertamente todo filme sufre desde su concepción de diferentes tipos de control, estatal, económico, ideológico, empresarial, pero en la España de posguerras el estatal tiene los medios para lograr su objetivo de acuerdo con la Iglesia, su socia desde los primeros momentos de la guerra civil. El control político vertical del Estado, la Iglesia y el Ejército se asocian y sólo paulatinamente la regulación de la vida social se comparte con otras instancias como el Opus Dei. La que nos ocupa es entonces una censura desde arriba, sin paliativos, que como siempre sucede conlleva la autocensura y obliga a los creadores a buscar formas alternativas para expresarse y a las audiencias a resistir la imposición de ideas por caminos diversos.

4 La conferencia es convocada por el círculo cultural Nosotros y se lleva a cabo en uno de los salones del CSIC (Consejo Superior de Investigaciones Científicas), con la intención expresa de exponer de la manera más clara y sencilla que fuera posible lo que su título enuncia, dejando muy claro el orador que lo hace a título personal pero también, que "hasta ahora el criterio y normas de las que voy a tratar han inspirado, en general, la 
actuación y resoluciones de la Comisión Nacional de Censura Cinematográfica"11. La obra consta de dos partes, ambas con subdivisiones. La primera es la que nos resulta aquí más rica porque da cuenta de los conceptos medulares que estructuran su mirada, en los que apoya la certidumbre de la magnificencia de su actividad. Comprende una introducción, seguida por varios capítulos: "Fundamentos de la doctrina", "Inmoralidad del cine", "Efectos perniciosos del cine", "Nuestro concepto del cine", "Recursos contra la influencia nociva del cine", "Criterios y normas de censura", y en una segunda parte plantea un Proyecto de Código moral de la Cinematografía española que explica a partir de las normas rectoras con que han venido actuando en la Junta, su proyecto de codificación, para concluir con un contundente Epilogo. El texto cuenta además con dos apéndices, uno es el Code de [sic] Production Standards, en inglés, y otro la Carta Encíclica de S.S. el Papa Pío XI acerca de los espectáculos cinematográficos, la conocida como Vigilanti Cura, dirigida principalmente al clero estadounidense y dictada en Roma el 29 de junio de 1936. Ortiz explica que su proyecto adapta el Code del anexo o Código moral de la Asociación Americana de Productores y Distribuidores de Películas, el que conocemos como Código Hays, a la realidad española y de hecho los doce capítulos del texto americano se adaptan, muy de acuerdo a una lógica católica, a un decálogo que conforma su propuesta.

5 En su Proyecto, Ortiz Muñoz se apropia del Code de [sic] Production Standards, pero argumenta mucho más en cada tema que los estadounidenses, más concisos y directos, además de modificar algunos aspectos para dar énfasis a sus propias obsesiones y para respetar a ultranza la Encíclica Vigilanti Cura. A modo de ejemplo: si el Código Hays habla de respetar la ley natural, Ortiz habla de la ley divina, sea positiva o natural ${ }^{12}$, en cambio no habla de la libertad y la motivación de quienes deben hacer el film moral, lo que sí hace el Code de [sic] Production Standards ${ }^{13}$. En las regulaciones ante los crímenes Ortiz Muñoz introduce el suicidio y el duelo, el aborto y la eutanasia, los estupefacientes, pero la ingesta de alcohol sólo si llega a la embriaguez ${ }^{14}$, cuándo Hays pone límites a la simple aparición de licores si no es necesaria para la trama ${ }^{15}$. Cuando ambos se refieren al sexo el Hays limita la representación del "adulterio", y Ortiz incluye también los "amores ilícitos", y cuando el americano limita el tipo de besos, el español incluye también el exceso de los familiares o afectuosos, porque "su aceptación como costumbre social ofrecería el peligro de derivar a lo prohibido" ${ }^{16}$. El Proyecto de Ortiz censura totalmente las escenas de prácticas abortivas, en el capítulo sobre sexualidad, pero excluye la prohibición de relaciones sexuales entre personas de distintas razas, que sí menciona el Hays ${ }^{17}$. También es más preciso en cuanto a la regulación de los bailes, pues si en Hollywood sólo debían fijarse en que no hubiera movimientos procaces, los españoles deben atender además que se levanten los pies del suelo $^{18}$. Notable es que el Code de [sic] Production Standards regula el respeto a cualquier religión, ceremonia, y a cualquier ministro del culto, que nunca debe aparecer como villano o comparsa cómico ${ }^{19}$, pero Ortiz pone límites estrictos a las blasfemias o gestos y precisa que no deben atacarse o exponerse principios contrarios al dogma católico ${ }^{20}$. Secunda en todo al Hays, pero está claro que tan sólo respecto a su propia Iglesia. También sorprende en el capítulo de Instituciones Nacionales que rebasa el respeto debido a la bandera, los héroes nacionales o las personalidades históricas, cuando respecto a éstas escribe que deberán tratarse con "criterio objetivo" ${ }^{21}$ dejando abierta la puerta a su personal interpretación, y además agrega que no se puede vulnerar la disciplina, el honor o el prestigio de las instituciones armadas. En asuntos repelentes sigue al Hays, pero excluye un punto, la prohibición de representar la venta de una 
mujer o de su honor ${ }^{22}$. Quizá considerara suficiente su inclusión en el apartado de no maltratar a niños, ancianos, mujeres, pero ciertamente permitió esta vez que se le escapara un punto importante, cuando por lo general la propuesta de Ortiz es mucho más amplia y detallista que la estadounidense. Para terminar la conferencia, se proyectaron trozos de cortes ordenados por la censura tomados al azar y que "merecieron la unánime repulsa del selecto auditorio", pero Ortiz declara que ha "desechado los trozos más sucios y obscenos" por respeto a la audiencia, y ha cortado algunos para "no molestar vuestra sensibilidad" 23 . Ciertamente el azar era relativo y la vocación por el uso de la tijera marcaba su conducta.

6 Las influencias explícitas dadas por Ortiz Muñoz son pocas, pero dan cuenta de la influencia del pensamiento eclesiástico. Menciona al Padre Antonio García D. Figar y su texto La moralidad en quiebra (1936), respecto a su concepto de amor que se muestra en las pantallas y a la influencia del cine en las audiencias. También menciona al Dr. Torres Torija en sus conclusiones al II Congreso Nacional de Ciencias Sociales en "Méjico" (sic), en la preocupación por la influencia que ejerce Hollywood en la mentalidad de los mexicanos; a un periodista del que no da el nombre, probablemente porque no está totalmente de acuerdo con sus argumentos pues se permite criticar moderadamente algunas decisiones de la Junta. Esta omisión indica el talante del censor, acostumbrado a cortar todo aquello que no lo secunda a pie juntillas. Declara la influencia evidente de la Carta Encíclica de S.S. el Papa Pío XI acerca de los espectáculos cinematográficos, Vigilanti Cura, (1936) que expresa su preocupación por el cine hollywoodense, en particular en la necesidad de proteger a niños y jóvenes, lo que el mismo Pontífice había abordado ya en la bula Divini Illius Magistri (1929) sobre la educación cristiana de la juventud. Lo que parecería más importante para Ortiz Muñoz es el Código Moral de la Asociación Americana de Productores y Distribuidores de Películas que fue redactado por el Padre Daniel Lord y asumido en 1930 por los productores, encabezados en ese momento por William H. Hays por lo que se conoce con su nombre. No tuvo carácter obligatorio hasta 1934, en que intentaron así que fuera cumplido y Ortiz menciona que lo conoció recientemente en España gracias al libro de Enrique Gómez, El guión cinematográfico (1944). Francisco Ortiz Muñoz hace notar que también utilizó una serie de notas anexas al documento principal, pero que no las pudo incluir en su publicación. Declara su acuerdo entusiasta con este texto y hace notar que gracias a él observó que en España están bien orientados, de manera que en la segunda parte de su intervención, en la parte concreta del Proyecto, lo adapta, como vimos a la que él considera realidad de la cultura española ${ }^{24}$.

7 Como era fácil suponer que alguna de las personas de la audiencia se preguntara por su calificación para tan complejo oficio, Francisco Ortiz Muñoz declara ser un aficionado al cine y aclara que "por oficio y por afición conozco casi toda la producción cinematográfica nacional y la extranjera venida a España de doce años atrás" ${ }^{25}$, o sea desde el año 1934, durante el llamado Bienio negro, cuando el gobierno era de centro, pero dependía parlamentariamente de una derecha que hizo todo lo posible por dar marcha atrás a los logros alcanzados. Dice que lo motiva, en primer lugar:

[...] la aplicación de los principios de la moral católica al problema de la censura cinematográfica y también el fruto de varios años de labor, de estudio, de meditación y de consejo y asesoramiento", pues "desde hace más de cinco años tengo la obligación por mi cargo de informar los guiones cinematográficos españoles y ejercitar la censura de las películas nacionales y de las extranjera en su 
versión original primero y luego en español, lo que supone ver cada película por lo menos dos veces ${ }^{26}$.

Se declara consciente del rechazo que su oficio suscita, pues "se ha criticado a los cuatro vientos la labor penosa del organismo censor, se ha dicho que está conformada por gente inexperta y se le acusa de cualquier corte, aún achacándole aquellos que son parte del propio film ${ }^{27}$. Observamos aquí que vive su rol de chivo expiatorio, esa idea muy cristiana de que el sacrificio debe soportarse con entereza, pues es parte de la penitencia que todo humano debe purgar. Estamos, pues, ante un profesional, que además tiene confianza en sí mismo y considera que con esta disciplina y experiencia ha adquirido un criterio "bastante acertado" porque se "enjuicia" el filme con una visión amplia "comparativa, serena y exenta de prejuicios o intereses particulares. La responsabilidad de la gestión le hace a uno desposeerse de todo afecto o inclinación partidista que no se encamine al bien común" ${ }^{28}$, lo que dicho al margen no se aprecia en muchos de los expedientes que aparecen sesgados por la doctrina católica, el ideario de Falange o los gustos personales. Ortiz considera que con su Proyecto, aplicado "con buena voluntad y con sentido común, tendríamos resuelto el problema de la censura" 29 .

Ortiz Muñoz plantea dos aspectos medulares: su supuesta neutralidad y la necesidad incuestionable del servicio que considera brindar y que muestra con orgullo a lo largo de toda su disquisición. El pájaro - dicen - no sabe de las condiciones climatológicas en las que vuela, ni del principio biológico que se lo permite, y para precisarlo está el ornitólogo. Ciertamente Ortiz Muñoz tampoco sabe, o no quiere declarar que está inscrito en un mundo que condiciona su mirada y sus conceptos, pues está tan seguro de su justicia que la duda no otea cerca de él. Ortiz se cree objetivo, cree que desvela el Bien al despojarlo del "cieno y la obscenidad", aunque más de uno podría pensar que simplemente era un cínico y un autoritario: su fe parece ciega, sin embargo no es ingenuo, y expresa la posibilidad de que a algún escucha la conferencia pudiera parecerle "un tanto o un mucho sermonaria", por lo que aclara con certeza que para dictar su conferencia es preciso hacerlo "desde el punto de vista de la moral católica, y en este sentido ni yo sé expresarme de otra forma, ni creo que, de acuerdo con la moral católica, pueda tratarse de distinta manera el tema" ${ }^{30}$, con lo que tenemos que el concepto de neutralidad de Ortiz es, ni más ni menos, el pensamiento de la Iglesia y él se observa como el portavoz de la única Verdad. Se considera a sí mismo objetivo y neutral porque no puede concebir otra moral que la católica, y por lo mismo, participar de ella no entra en su concepto de "prejuicios o intereses particulares [...] afecto o inclinación partidista que no se encamine al bien común" ${ }^{31}$. El talante es claro: sólo una de las dos Españas es la victoriosa y a la otra ni se la ve ni se la oye: se la suprime por todos los medios que sean necesarios, incluso el ninguneo.

Sabemos que, pese a su deseo, la sociedad española no era simple y que las tensiones cruzaban exacerbadas por ese mundo todavía dividido entre rojos y azules, azuzadas por el miedo, y aunque a algunos éste les obligara a callar eso no significaba el convencimiento general. Sin embargo, Ortiz Muñoz concluye con una "explicación no pedida [o séase] una acusación manifiesta": "Me precio de no ser ñoño, ni timorato, ni mojigato" ${ }^{32}$, pero agrega que si así se califica al "hombre que procura ser íntegro, seriamente religioso, piadoso, recto" entonces quizá sí merecería esos calificativos. Declara que ha rebasado los cuarenta años, que es padre de ocho hijos y "tiene en su haber... muchas horas de vuelo", según leyó a sus audiencias de esa tarde ${ }^{33}$. Las influencias declaradas son, de entrada, como vimos, la moral católica con el carácter incuestionable de Suma Verdad y el axioma de la necesidad de la censura, que está 
presente en todos los países civilizados, “aún aquellos que pregonan y practican la más amplia libertad de expresión" ${ }^{34}$, pues atiende un problema "de enorme importancia y de indiscutible trascendencia social" ${ }^{35}$. Cada país lo adapta a su idiosincrasia y/o su ideología, pues no puede ser visto de acuerdo a conductas extrañas o puramente naturistas o artísticas ${ }^{36}$. Así lo vemos: montado sobre el Código Hays y la Encíclica papal de Pío XI que muestra su complacencia porque algún gobierno (no especifica cuál) ha creado comisiones de censura y ha dirigido la industria fílmica nacional a realizar películas adecuadas ${ }^{37}$. Ortiz establece normas que le parecen esencialmente españolas, como el bloqueo al erotismo y a la sexualidad, el peso de la religión y algunos otros aspectos.

11 El mundo en el que se mueve Ortiz Muñoz es de certezas, pero muy amenazadas. Ciertamente lo que parece de sentido común, lo "obvio", es lo más difícil de discernir tanto para el observador externo o extemporáneo como para quienes participan de un supuesto. Éste forma lo que Michel Foucault llama un "sistema de verdad" 38 que pauta las creencias y el conocimiento y hay un punto ciego que sólo mediante el análisis se puede comprender. Ortiz se da cuenta de que el cine es un producto cultural y que cada país tiene sus normas, pero no percibe sus propias ideas como producto de una cultura católica que lo moldea rígidamente y por eso, "los fundamentos doctrinales en que se basan mis apreciaciones" ${ }^{39}$ le parecen de una verdad absoluta, pues discrepar de las "verdades" dictadas por Dios y sus agentes es hacerlo no de una opinión sino de un dogma divino. De entrada, entonces, no cabe con él la discusión. Ortiz Muñoz lo sabe y lo que trata de exponer son las dificultades de una práctica de "enjuiciamiento" que debe realizar el Estado desde el momento en que el Movimiento Nacional se declaró católico, debiendo asumir "las normas morales y dogmáticas del Catolicismo como ley fundamental de su actuación en cuanto a Estado. Remover las causas de pública corrupción, así en el orden de las ideas como en el de las costumbres es obligación de todo Estado ${ }^{40 "}$. La palabra de Dios tiene que imponerse en la tierra y un Estado católico tiene la obligación de establecerla firmemente y para eso institucionalizar la censura que construya una mirada católica en todo aquello que tenga importancia social, debe "prohibir y eficazmente impedir [...] todo acto público de trascendencia corruptiva, ya en la región de las ideas ya en la de la moral", y hacerlo de la misma manera y con el mismo sentido con el que un padre cuida la conducta adecuada de sus hijos ${ }^{41}$.

El Estado tiene entonces la obligación de imponer un código cultural para cumplir su función paterna, pero tiene una guía: la Iglesia y el dogma. Tiene también un fin: la santificación de las costumbres y la imposición de la doctrina evangélica. En esa cruzada del Estado se deben atender tanto los bienes materiales como los espirituales, ambos necesarios "para el buen ser o digna vida de la sociedad civil" ${ }^{42}$. También Pío XI en su Encíclica habla de que el cine, la ciencia, la cultura deben dirigirse a la gloria de Dios y "a la extensión del reino de Jesucristo en la tierra", así que Ortiz no está solo en esta peculiar empresa ${ }^{43}$. Se trata de construir el territorio de Dios en la tierra, pero los hombres chapotean en el barro y la obra de la Comisión Nacional de Censura Cinematográfica, expresa retóricamente Ortiz, no ha estado exenta de los errores involuntarios que tienen a menudo las obras humanas, "aunque en ella se ponga la mejor voluntad e intención" ${ }^{44}$. "Es cierto [que] en las tareas de la censura, como en todas las obras humanas, los errores han sido muchos; pero el propósito, la intención, el criterio que propugno son nobilísimos y absolutamente ortodoxos", ergo, cabe agregar, "verdaderos" $"$. He ahí el proyecto que se quiere construir y que involucra un concepto de nación para el que el Estado español realiza un proceso paralelo: al mismo tiempo 
que establece la censura, fomenta la industria cinematográfica como un instrumento de control político e ideológico. En España, la Ley sobre Ordenación y Defensa de la Industria Nacional regula una actividad que se considera importante y que desde 1941 cuenta con subvenciones dadas ex profeso al Sindicato Nacional del Espectáculo, afiliado a la Falange, para su desarrollo, entre otras medidas a favor de la industria que fueron muy importantes. Tanto la censura como el fomento fílmico sirven al proyecto de una nación particular, una que imaginan como sucursal del paraíso en la tierra.

La censura regula el contenido de las películas desde el primer momento, aprobando o no el guión, y pauta su factura, distribución, exhibición y consumo, la publicidad de diferentes órdenes, sea impresa o fílmica (el trailer), los stills que adelantan como fotofija desde los vestíbulos de los cines lo que se verá en pantalla, las revistas y todo cuánto se relacione al cine. La llamada doble censura, primero sobre el guión y después sobre el filme terminado, da cuenta de la conciencia de los censores acerca de las múltiples maneras en que en un filme se traslapan contenidos y ellos quieren tenerlos controlados todos, pues podrían atentar contra su cruzada. El cine extranjero se escapa de la censura al guión y las películas foráneas de habla castellana del permiso de doblaje, que también está sujeto a censura. La Junta puede manipular la cinta cortando escenas o secuencias, cambiando los diálogos y una vez "enjuiciada" puede declararla autorizada, tolerada, recomendada o de plano prohibida, y con estos recursos cree negociar entre las necesidades del público de distraerse y las de la censura de protegerlo de las amenazas que se ciernen sobre él.

La Iglesia tiene un papel medular en la Junta, mediante un delegado eclesiástico para los temas morales, con poder de veto. Más tarde contó además con una instancia propia que clasificaba los filmes: la Comisión Episcopal Española de Cine, Radio y Televisión, que en 1960 publica una Guía de películas estrenadas ${ }^{46}$, que abarca los años 1954-1959 pero incluye filmes anteriores que se seguían exhibiendo. Hace énfasis en los valores católicos y los enfrenta con las exigencias comerciales muy fuertes en el medio y explícitas en el cine de Hollywood, con su exigencia de dinero y éxito, la exaltación del individualismo y las que llama "pasiones salvajes" o los "instintos".

\section{Arrogancia, prepotencia y construcción cultural}

En "Elogio de la templanza" Norberto Bobbio distingue, sin carácter axiológico sino analítico, entre virtudes débiles y fuertes en quienes tienen el oficio del gobierno ${ }^{47}$. Algunas de las virtudes típicas de los poderosos son la firmeza, la valentía, la audacia, la generosidad, y se manifiestan en la vida política y en la guerra ${ }^{48}$. Para los héroes es lícito lo que no lo es para el hombre común, incluso los excesos y el uso de la violencia en aras de ser magnánimo y/o victorioso, pero Erasmo planteó como vicios la arrogancia, la perversidad y la prepotencia y como cualidades la clemencia, la equidad, la prudencia, la benignidad, la cautela, la honestidad, entre otras ${ }^{49}$, y Bobbio destaca la templanza, opuesta a la opinión exagerada de los propios méritos (la arrogancia ) y del abuso de potencia ostentada y ejercitada (la prepotencia) ${ }^{50}$. La templanza arropa a la tolerancia y al respeto a las ideas y formas de vivir de los otros y permite la misericordia y la compasión ${ }^{51}$, sentimientos exaltados por el cristianismo. Estas cualidades parecen ajenas a la clase política española en 1946 y especialmente al aparato censor. Probablemente su arrogancia y prepotencia provienen de lo que Michael Oakeshott ha llamado "política de la fe", una categoría de análisis que permite 
enmarcar un estilo de ejercer la política opuesta, aunque coexistente en la realidad, con la que el llama "política del escepticismo" 52 . La primera implica la confianza en que el Estado puede lograr la prosperidad y la perfectibilidad humanas, no en un sentido religioso, aunque en nuestro caso así sea, sino mediante el poder y los instrumentos políticos, mientras que los escépticos no consideran esto viable ni creen en una verdad única, y sólo pretenden que el Estado preserve la paz y el orden, la seguridad y los derechos individuales, aceptando que el hombre es un ser falible y sin intención de redimirlo. Quienes se inscriben en la opción de la fe suelen aceptar gobiernos omnipresentes y autoritarios que controlan a la sociedad para perfeccionar a sus miembros, y a menudo son regidos por el dogmatismo y olvidan el Estado de derecho. Parten de cierta fe en la humanidad, puesto que ésta es perfectible, junto con una enorme fe en la fuerza política. Los escépticos suelen ser conservadores, pero en Ortiz, que lo es y mucho, observamos esta confianza en el poder político, aunque lo mezcle con el dogma católico, algo normal por cuanto el Estado ha asumido oficialmente esta religión. En algunos aspectos esta postura resulta contradictoria con otros de sus postulados, como veremos.

El mundo político abarca muchas cosas. Incluye una dimensión simbólica que implica a la cultura y a los imaginarios sociales, o sea las formas de percibir y de imaginar el mundo, con los que los seres humanos se conceptualizan a sí mismos. Un imaginario no es sinónimo de mentira, aunque diste de la objetividad. Está presente en toda situación humana, conformando un concepto de la vida que lo permea todo: las clases sociales desde que las hay, las diferencias étnicas desde que el contacto geográfico las hizo evidentes, la diferencia sexual que deviene en géneros, las formas de ejercer el poder. Todo aspecto histórico está indisolublemente ligado a lo simbólico, como condición necesaria para su existencia, aunque no se reduzca a ello. Los Estados han tratado de construir ese territorio cultural de determinada manera, pues como ha explicado Roger Bartra, determinadas redes imaginarias son necesarias para establecer cualquier tipo de orden político ${ }^{53}$. Así por ejemplo, no podría implantarse un régimen dictatorial en una sociedad cuyo imaginario cobijara ideas de democracia y libertad de expresión como un derecho inalienable. Al estar inmersos en una sociedad todos participan (participamos) de lo que Foucault ha llamado un "sistema de verdad" que pauta el conocimiento y las creencias, pues implica un código aceptado y reconocido socialmente, construido en un largo proceso histórico ${ }^{54}$. Sin embargo los victoriosos quieren hacerlo expedito, dado que cuentan con los medios y el poder para pretender convertir su ideología en "dominante" ${ }^{55}$, pero este proceso no se impone sin mediar con otros sistemas de ideas, por ejemplo las que han sido llamadas mentalidades ${ }^{56}$, concepto muy parecido al que José Ortega y Gasset llamaba "creencias", ideas en las que estamos inmersos y desde las que vivimos la vida sin reflexionar sobre ellas ${ }^{57}$, que conforman nuestros prejuicios y son de una enorme importancia para construir nuestros imaginarios.

Imponer una ideología de manera radical es empresa ardua y seguramente imposible, porque en toda sociedad existen ideas de diversa índole, en constante tensión, campean contradicciones, posibilidades diversas y límites de la mirada, y modificar las fronteras de la percepción implica mediar con las resistencias: "Donde hay poder hay resistencia" 58. Para penetrar en las voluntades, el poder debe hacer acopio de recursos y concesiones a las ideas previas o de otro orden, como plantea Antonio Gramsci y sólo así puede lograr el consenso y, quizá, la hegemonía ${ }^{59}$. El franquismo se lo propuso, muy 
de acuerdo a su estilo autocrático, pues tenía medios poderosos para lograrlo y la censura es una de las herramientas con la que intentan conformar un imaginario adecuado al régimen político. La maquinaria censora, que puede ser sutil o burda, evidente o discreta, implica una voluntad de construir una mirada del mundo, sólo una, y una forma de construcción de lo visible. Implica una percepción de lo que es peligroso, un inventario de los temores y un catálogo de lo debido, que nos permite ver las fobias y las filias de un grupo de poder y da cuenta de la arrogancia del grupo que lo ostenta, tan lejos de la templanza erasmiana. Saber hasta dónde lo logró sería otro tema, pero lo que el texto de Ortiz Muñoz nos permite analizar son las ideas de su pretensión, que tienen sentido de acuerdo a una lógica autocrática del poder. Vistas así las cosas es importante precisar ¿qué se puede ver y oír en cada época?, ¿qué se puede construir a partir de eso?, ¿cómo se dan los cambios?, ¿hasta dónde pueden realizarse, recibirse e integrarse? Al tratar el tema de la censura abordamos la arrogancia y la prepotencia de un grupo que quiere modificar en forma tajante la cultura y la mentalidad, en base al argumento de su Verdad, así, con mayúsculas. Si el mapa cultural en la España de los años treinta permitía opciones diversas, el ensamblaje que se impone con la victoria del franquismo trata de acotar el territorio imaginario en un único sentido, lo que configuraría, a su vez, las normas de conducta, de distinción y de buen gusto ${ }^{60}$.

Hablamos de "cultura" como un conjunto de valores, costumbres, creencias y prácticas ligadas a una forma de vivir la vida, un código de significación que permite a los individuos de un grupo interactuar entre sí, que incluye los imaginarios tanto como los símbolos compartidos que los expresan y las representaciones en que se encarnan, que muchas veces son hechas con imágenes ${ }^{61}$. El cine es importante por eso, porque los imaginarios están hechos en gran medida de imágenes y no sólo transmiten contenidos sino que los construyen, pues hacen visible y/o concebible cosas que antes no lo eran. Y la cultura que tratan de negar estos franquistas es sólida y poderosa. En España, el mundo intelectual de los años treinta había sido muy intenso y había heredado debates que se remontaban al siglo XIX, cuando se hablaba en forma insidiosa de las dos Españas, idea que Antonio Machado retomó para caracterizar dos proyectos de país, dos formas de comprender el mundo: la una apostando por el progreso, la libertad, la democracia y con profunda confianza en el pueblo como quintaesencia de la humanidad, demandando una sociedad laica, buscando formar ciudadanos en lugar de súbditos, de establecer las pautas para la modernidad mediante el dominio de la Ley, modificando la vieja y añeja tradición que se resistía a darle paso, mientras que la otra pretendía la conservación de los privilegios y del statu quo reinantes, el que organizaba una vida basada en los linajes y las tradiciones del Antiguo Régimen, con una importancia fuerte de la Iglesia y del Ejército. Estas posturas se han presentado como un binomio excluyente y radical, lo que puede parecer algo simple, pero tiene la virtud de organizar las ideas al señalar los dos polos extremos, que esconden los matices de muy diversas opiniones y proyectos: la "nueva" y la "vieja" España. En ambos casos sus adeptos se han sentido poseedores de la "verdadera", la "esencial" y consideran que el otro bando la usurpa, que la de "los otros" es simplemente falsa. Las dos posturas no sólo fueron antitéticas sino excluyentes. El llamado "problema de España" enuncia la pretensión de dilucidar su "ser" o "esencia" y se convierte en una obsesión que discuten los intelectuales en la primera mitad del siglo XX en forma incontinente, y también en el argumento que algunos esgrimieron para provocar la guerra civil. La Segunda República española está marcada por un ideal ético y estético que atraviesa 
todos los órdenes de la vida. Muchos de esos ideales son expresados con precisión por la Institución Libre de Enseñanza, escuela más que pedagógica, con un amplio carácter humanista. Las ideas que sostienen a la Institución se basaron en el krausismo, que puede considerarse más un estilo que una actitud intelectual o una doctrina ${ }^{62}$. La religión no tiene para estos liberales el carácter tradicional, pues consideran inteligible la existencia de una causa suprema rectora de la vida en la que están inmersas tanto las cosas físicas como las espirituales, lo que propicia la supremacía de la ciencia y de la razón para dirigir el conocimiento y regir las relaciones humanas ${ }^{63}$. Mediante una investigación ordenada y sistemática puede conocerse al Ser Absoluto y para eso priman la libertad de investigación, la educación y la ciencia, que se enriquece con otros valores y con la idea misma de secularización. La Institución Libre de Enseñanza, avanzada del liberalismo, procura un pensamiento y un imaginario adecuado para crear a un hombre con confianza en su propia razón y en sus derechos elementales. Para Francisco Gíner de los Ríos era una tarea nacional, por lo que en 1880, en la ceremonia de apertura de cursos declaró: "Vamos a redimir a la Patria y devolverla a su destino". Es, pues, un proyecto regeneracionista ${ }^{64}$, en el que la fe está presente, pero también la templanza. Durante la Segunda República este ideario librepensador tiene mucha influencia, se difunde e incluso trasciende el carácter de elite que había tenido para abarcar sectores más amplios que se vieron beneficiados de sus conceptos de humanidad y progreso. Esta esperanza se vino abajo con la victoria de los llamados nacionales, y aunque no se puede argüir que fuera hegemónica sí era un horizonte de aspiración.

Ciertamente la censura implica un problema ético, y aunque ha sido un tema de larga duración, esta dimensión particular sólo pudo entenderse cuando se puso en cuestión el derecho a ser informado y a la libre expresión, que se debatió en Francia desde 1789, y sólo lo decretó la ONU como un derecho en 1948, después de dada la conferencia que ahora trabajamos. Para más, el control que establece la censura es previo al supuesto daño que se produciría, lo que la coloca en una situación ilegal o alegal, que paradójicamente legaliza lo arbitrario y castiga por un daño no realizado. Estas cuestiones no preocupaban a Francisco Ortiz Muñoz, fuertemente blindado para cualquier opinión que no coincidiera con la suya. La censura se dirige a toda actividad social, pero lo hace quizás con más énfasis cuando se trata de áreas de la cultura o del entretenimiento, como lo es el cine, por cuanto la enorme importancia de las ideas y de las imágenes en la conciencia de la gente, por su carácter comercial e industrial de índole masiva, que pone en duda que sea un arte y por la enorme fuerza de su lenguaje que procura un efecto de realidad superlativo. En la Iglesia católica, y por lo tanto en la cultura española no hay iconoclastia, antes bien las imágenes son bienvenidas para la doctrina, lo que crea un terreno de aceptación de las artes plásticas y del cine, pero la institución ha cobijado una censura fuerte. En la primera mitad del siglo XX, además, están muy conscientes de la preeminencia del sentido de la vista y de la importancia de la cultura visual en Occidente ${ }^{65}$ y Michel de Certeau hace notar que a partir del siglo XVII lo visible asume el prestigio de lo real, mientras que el mundo interior, invisible, se convierte en terreno misterioso y del que se desconfía ${ }^{66}$. En el siglo XX, los estudios sobre los públicos remarcaron la influencia de lo visual en sus audiencias que se pensaban inermes y pusieron sobre aviso a quienes creían poder construir una forma de mirar, y de esta manera un imaginario y una cultura. En los años posteriores a la Segunda Guerra mundial, los estudios sobre la comunicación de masas en los Estados Unidos de América surgen de la psicología y centran la atención en los espectadores, 
para ver hasta dónde se puede influir en ellos, mientras que en Europa el debate gira además en torno a su papel de arte y su carácter pedagógico, dando peso a la cuestión ética. La influencia en la niñez y la juventud es una preocupación muy especial desde los años treinta y las teorías giran en la suposición de un aprendizaje indiscriminado por parte de ellos, de acuerdo con la teoría de la "aguja intradérmica", en que el mal penetraba las conciencias como si fuera una sustancia inyectada. En ese sentido, Fredric Wertham publicó en 1954 el libro La seducción de los inocentes que causó un gran impacto. En su Encíclica de 1939 también el Papa Pío XI se preocupa del carácter masivo del cine, de la heterogeneidad de las audiencias y de su supuesta pasividad ante las imágenes en movimiento ${ }^{67}$. En los difíciles años cuarenta, en los que no sólo había en España precariedad económica sino también una férrea represión política e ideológica, la censura fue una de las herramientas principales para construir el imaginario de sus habitantes, manejada por un grupo en que algunos estaban ávidos por instaurar el reino de Dios en la tierra. La situación ha merecido enfado e insultos, pero es necesario entender el carácter de la propuesta, porque pautó en forma importante a la sociedad española.

\section{Función de la censura según Ortiz Muñoz}

Como vimos antes, Ortiz Muñoz no duda en ningún momento en la necesidad de la censura y para esta inclinación se basa en el dogma establecido por "las grandes verdades religiosas, teniendo en cuenta la innata inclinación del hombre al mal, ya que perdimos por el pecado la inocencia primera. Y dentro de esta malicia común a todos los mortales" circulan las películas ${ }^{68}$. Este concepto del ser humano está detrás de todo el proceso fílmico según el censor, y de él participan todos, tanto las potenciales víctimas como los victimarios, por eso pretende proteger a los incautos espectadores de cine, especialmente a los niños y jóvenes, y hacerlo por anticipado, acusando a las películas de lo que hoy llamaríamos un delito de intención: dado que para la doctrina existen los pecados de pensamiento, palabra, actuación u omisión, se evita caer en el último de ellos, para evitar los otros a los espectadores. Sin embargo, su prepotencia resulta chocante, pues este hombre caído redimible por la política cultural del Estado supone una calificación excepcional en los censores, una arrogancia cobijada en la que Oakeshott llama una "política de la fe".

Resulta notable el contraste respecto al pensamiento liberal español. La Institución Libre de Enseñanza, como portavoz del liberalismo intentó eliminar la idea de "la culpa", pilar del catolicismo y buscó la armonía entre los hombres y entre ellos y la naturaleza, con la idea de que los seres humanos son buenos por naturaleza y tienen dignidad, y que estos rasgos los desarrolla una educación adecuada. Era por eso medular el respeto y la confianza en los niños y en su independencia, sin pretender condicionarlos en ningún sentido. Ciertamente toda idea se nutre de otras previas y las ilustradas sostenían este andamiaje. La idea de la bondad y el valor intrínseco de las personas proviene de las Luces, y ofrece los argumentos para limitar el papel social de la Iglesia y de la monarquía, aspira a que la sociedad se constituya por ciudadanos y no por súbditos o fieles devotos, y a desarrollar un pensamiento racional y crítico. En España el debate apareció desde la época de Carlos III, marcadamente en el pensamiento de Feijoo y Jovellanos. El krausismo tomó de estos elementos para propugnar el valor intrínseco de los seres humanos y la igualdad de todos ellos. Ideas 
opuestas, totalmente contrarias a las que vemos en Ortiz Muñoz. Su concepto del hombre caído deriva de la doctrina católica, y si bien en toda sociedad conviven en tensión conceptos diversos y aún contradictorios, en la España de 1946 el poder del Régimen era enorme y la presencia liberal aún derrotada parecía ser todavía temida por ellos, cuando tanto tenían que insistir en contradecirla, por lo que la radicalización de sus opiniones era tan fuerte. La censura busca imponer una ideología que se quería dominante, y si bien latía en la tradición española y no se había convertido en residual ante la avanzada liberal republicana, sí se había cuestionado acremente. En la posguerra quienes ganaron lograron que "la culpa" volviera a ser hegemónica ${ }^{69}$. Sólo una de las dos Españas era la victoriosa.

Con Michel Foucault tenemos claro que cada época histórica tiene un marco limitado de percepción ${ }^{70}$, pero también que éste no es inmutable y que la historia lo penetra y lo modifica todo. Como explicó en 1964 Umberto Eco, "toda modificación de los instrumentos culturales, en la historia de la humanidad, se presenta como una profunda puesta en crisis del 'modelo cultural' precedente" ${ }^{\text {"1 }}$. En este caso del liberalismo español, que aunque no fuera dominante y conviviera con latencias tradicionales, era peligroso. Una pintura, una película, una novela, una canción pueden serlo porque posibilitan una mirada específica, permiten concebir ciertas cosas y aún convertirse en modelo para las prácticas individuales y colectivas. El campo cultural ${ }^{72}$ que se impone se define por un capital de ideas tradicionales avalado ampliamente por el poder político y por el control de los medios. Los discursos del poder penetran en las conciencias y en los cuerpos al grado de encarnarse incluso en los que Pierre Bourdieu llama Habitus, o sea gestos, gustos, hábitos, formas de pensar y sentir que se internalizan y se expresan con el cuerpo y en sus actitudes. En gran medida se aprenden en las pantallas, estableciéndose como formas de distinción y buen gusto. En este caso son actitudes que denotan un concepto del estoicismo, el honor y la dignidad, la modestia y la devoción al régimen y a la Iglesia. Así dice Ortiz en su Proyecto que "las expresiones groseras, vulgares o plebeyas no serán permitidas" pues debe seguirse el "buen gusto"73. Por supuesto la desnudez total o parcial se veda y la ropa no debe realzar en forma provocativa el cuerpo o sus partes, y deben evitarse transparencias y telas translúcidas ${ }^{74}$. Así condicionan un estilo, pues como escribe Pierre Bourdieu, el cuerpo y las técnicas corporales se convierten en un capital físico que nos identifica con determinado estatus social y/o económico ${ }^{75}$, algo especialmente importante en esa sociedad estamental y de linajes que se reacomodaba después de la Segunda República.

Una mentalidad católica implica supuestos, creencias, prejuicios, redes imaginarias que tienen el plus para el régimen franquista de permitir que sus acciones sean soportadas.

Así por ejemplo, la idea de que el perdedor en el mundo terrenal será el futuro ganador del paraíso, y de que el ser humano sólo se redime mediante la pérdida y el sufrimiento; la que considera los enemigos fundamentales del ser humano a los placeres, la ambición, y la carne; en la diferencia y jerarquía social y de género sexual como si fuera de origen divino y por ende como algo esencial y eterno. En términos del orden social esta mentalidad sirve y propicia un concepto del Estado autoritario y ajeno a los intereses populares, una sociedad organizada en grupos radicalmente separados, al tipo de estamentos de Antiguo Régimen, que avala privilegios para un grupo con un peso determinante del linaje frente al individualismo y al libre esfuerzo, con lo que no se prepara a la gente para entrar a la modernidad ni a demandar derechos humanos; aceptar la idea de que la Ley no se aplica en forma igualitaria ni existe la seguridad 
jurídica ni el Estado de derecho, lo que obliga a la resignación y requiere de la esperanza, aceptar la fatalidad porque así dictó Dios las cosas. Esta España parecía estar hecha de una vez y para siempre. Para construir las redes imaginarias adecuadas, Ortiz Muñoz caracteriza con cuidado sus "fundamentos doctrinarios", que muestran desde el título su carácter religioso. En este escenario, el cine de casa, el español, asume una postura ideológica precisa y por eso se insiste en que la industria empieza con la Victoria. El cine extranjero es más peligroso y los censores se muestran especialmente atentos a las diferencias culturales y prestan mucha atención al hollywoodense, que ocupa crecientemente las apetencias de los españoles, pero que encarna la amenaza al proponer un concepto del ser humano y de la sociedad más amables, lo que resulta subversivo. Éste es otro punto medular que desarrolla en el capítulo intitulado Inmoralidad del cine, en el considera que:

El cine, desde su invención hasta la fecha ha sido fundamentalmente frívolo y falso. Desde el punto de vista moral [...] puede afirmarse casi rotundamente que el cine es malo. Defiende y difunde por lo general un concepto y sentido de la vida una apología o interpretación de las pasiones humanas una visión utilitarista o materialista del bien, del amor, de la moral y de las costumbres, contrarios, o por lo menos distintos, de la concepción cristiana que nosotros tenemos del bien, de la verdad, de la virtud, del amor, de la vida, de la muerte y del más allá. El cine es el vehículo más eficaz de modos de ser, de costumbres, de sentimientos, de fobias y de filias. $^{76}$

"Nosotros" se refiere por supuesto al grupo religioso inserto en el Estado. Pero también en su Encíclica, el Papa considera necesario poner un "freno a la maldad del arte cinematográfico"77. Además de malo es poderoso por tres de sus características básicas: los intereses comerciales y su naturaleza industrial, su carácter masivo y la enorme fuerza de su lenguaje. El poder de las imágenes es de sobra conocido y en la primera mitad del siglo XX se insiste sobre él. La imagen influye en las emociones de sus públicos y a menudo limita su reflexión, se considera caldo de cultivo para la irracionalidad de las audiencias. Su lenguaje llamado onírico por estar construido con símbolos y metáforas y ser similar a la forma de soñar es recibido en un ámbito peculiar, en dónde la imagen y el sonido de la pantalla focalizan la mirada y el oído, y todo ello lo vincula con deseos y pulsiones inconscientes de los espectadores, partes reprimidas por la cultura que los convierten en potenciales violadores del orden, agentes de lo instintivo, lo biológico y lo meramente anímico que amenaza el ansia de controlar la animalidad humana con el raciocinio. En el Preámbulo de su Proyecto Ortiz Muñoz plantea que "La gente puede llegar a acostumbrarse al asesinato, la crueldad, la brutalidad y otros hechos reprobables, si son reiteradamente expuestos"78, y en el Proyecto dice que la aparición frecuente de éstos tiende a rebajar el "respeto a lo sagrado de la vida"79. Ortiz Muñoz sabe de los sutiles mecanismos de transmisión, por eso recurre otra vez el orden cristiano: "En el principio fue el Verbo". Román Gubern plantea que "la imagen tiene una función ostensiva y la palabra una función conceptualizadora: la imagen es sensitiva, favoreciendo la representación concreta del mundo visible en su instantaneidad, y la palabra es abstracta" ${ }^{80}$. Para los censores, su palabra permite ordenar, clasificar, clarificar, distinguir y limitar la potencia de las imágenes en movimiento. Ortiz Muñoz en el Preámbulo a su Proyecto lo dice así: "el libro describe; la película muestra la realidad con detalles más vivos e impresionantes" de manera que las frías páginas no se comparan con "la película [que] hiere la vista y el oído a través de la directa reproducción de los sucesos reales o fantásticos" ${ }^{81}$. Representa una "atracción, espectacularidad y presentación vibrante y sugestiva de los 
hechos llevados a la pantalla, determinan una más íntima y profunda reacción en el público y una mayor influencia emotiva que cualquier otra forma de representación artística" ${ }^{82}$. El poder de la imagen se vislumbra como algo húmedo que penetra sutilmente las conciencias, el de la palabra es secante, determina que es lo correcto para el "orden de las cosas" que se desea. Foucault nos dice que "Es necesario concebir el discurso como una violencia que se ejerce sobre las cosas, en todo caso como una práctica que les imponemos" ${ }^{\prime 3}$ y que no está previamente significada, sino que se construye sobre su marcha. Lo primero que se prohíbe en la cultura occidental, agrega, son la sexualidad y la política ${ }^{84}$.

En su Encíclica de S.S. el Papa Pío XI acerca de los espectáculos cinematográficos, Pío XI entiende la necesidad de esparcimiento en cuerpo y espíritu de la gente, pero insiste en que sea digna del "hombre racional" y conforme a la "integridad de costumbres" ${ }^{85}$. El "cine", generalizando el término, es el hollywoodense que se convierte en "el otro", el anverso necesario para la propia definición. Las películas deben de defender y difundir un concepto de la vida dirigida a la trascendencia y al amor al prójimo, respetuoso de la moral y de las costumbres católicas. El censor señala la influencia fílmica a la ciencia médico-moral para contribuir al conocimiento y por lo tanto a la enmienda. Supone que esas películas producen desviación afectiva, depauperación orgánica, hastío al trabajo, substitución del "yo" por el héroe peliculero ${ }^{86}$, y cita al Dr. Torres Torija que consideró que los problemas del cine de Hollywood no son adecuados a la idiosincrasia del mexicano por fomentar un apetito sexual no adecuado para el carácter y sensibilidad latinos, un instinto de matonería y pistolerismo impropio de pueblos violentos, desmedida ambición de lujos y comodidades no adecuadas a la situación económica del país, importancia otorgada a la apariencia material y condición económica de las personas más que a su conducta moral, inclinación al alcoholismo y la vagancia, falta de responsabilidad de los padres e incomprensión de los hijos hacia sus desvelos, "tendencia de la mujer a obtener mayor libertad, que con justicia debe concedérsele, pero sin que raye en los límites del libertinaje" 87 , "disminución por parte del hombre de la estimación de la honra de la mujer"88. Ortiz también considera adecuada la crítica que hace respecto a los aspectos patrióticos, por la "ridiculización del tipo racial hispánico; abandono de las costumbres y hábitos típicos; formación de una psicosis bélica para beneficio de otras naciones; creación de un complejo colectivo de inferioridad física, cultural, económica y militar". Estas notas son para Ortiz, "bien claro está", también adecuadas para las españolas, al afectar el concepto de la juventud, la familia y la patria.

27 Las potenciales víctimas, seres caídos, inermes, un poco bobos, son carne crédula a la que es fácil engañar en territorios delicados como son el amor, el erotismo, el patriotismo, la política o la religión, y en el concepto del ser humano de sí mismo. Estas personas podrían pensarse merecedoras de ciertos beneficios, aún sin ganárselos a pulso, sin sacrificio ni sufrimiento, por ejemplo aspirar a la igualdad social o creer que la diferencia de clase no ha sido dictada por Dios. En fin, las audiencias podrían irse con el mal disfrazado de esas alegres imágenes que parecen tener vida propia en las pantallas. El demonio tienta y nuestro censor busca en la gente la chispa divina, pero soslaya los otros rasgos humanos como son la racionalidad, la crítica, el mal, la tentación, el deseo sexual y erótico, el anhelo ético, tan presente en el liberalismo previo. Los victimarios, los productores y comerciantes de cine también chapotean en el barro: "Se ha dicho que la mayoría de las empresas cinematográficas 
estadounidenses son judías. Si esto es verdad está claro el problema" 89 , pues "el judaísmo es enemigo del cristianismo, esto es, enemigo de la moral cristiana" y su poder en Estados Unidos de América es enorme. Lo curioso es que simultáneamente ese país le ofrece el Código Hays, que Ortiz Muñoz admira tanto como a la Vigilanti Cura.

A estos males se agrega la "perniciosa influencia del cine" ${ }^{\text {" }}$, de manera que la amenaza se duplica. Ortiz Muñoz no quiere ofender a los expertos y aclara que “

[...] la censura no se ejerce sólo para los críticos o para las personas inteligentes, sesudas, formadas, sensatas o corridas. El 'cine' es hoy día el espectáculo de las multitudes, la diversión más popular, y al pueblo, al honrado pueblo, no se le puede aplicar el mismo criterio ni la misma norma que a una minoría selecta. ${ }^{91}$

Haciéndonos recordar a esa sociedad de estancos sociales definidos: al cine van, explica en el Prámbulo al Proyecto, "cualquier categoría de personas, maduras y no maduras, cultas y poco instruidas, buenos ciudadanos y delincuentes [...] espectadores de cualquier clase o cualquier categoría social o intelectual"92. Por eso, las medidas que se toman son de moral pública y sólo molestan a "un grupo de seudointelectuales extranjerizantes, comunistoides, snobs, frívolos, o los comerciantes de la carne a quienes, desde luego, perjudica en su negocio el que se les prive de regodearse con la vista de unas pantorrillas o unas nalgas femeninas al aire" ${ }^{93}$ y Ortiz declara enfáticamente que la opinión de estos "ciudadanos" le tiene sin cuidado. Porque otro problema del cine es el ser un espectáculo de las multitudes y que "audazmente, ha sobrepasado los límites ante los que hasta ahora se habían detenido todas las otras manifestaciones artísticas dedicadas al gran público"94. Es un vehículo cultural que "impera en la ciudad y en el campo ha llegado a los últimos rincones de los más apartados lugares" ${ }^{\prime \prime}$, homogeneizando formas de comprensión, con lo que las diferencias sociales por orden divino o de naturaleza se diluyen resultando peligroso para "la juventud, la familia y la Patria españolas" ${ }^{\text {. }}$. El cine modifica formas de vida y de cultura que se están haciendo universales al ser:

Uno de los elementos modernos más poderosos y eficaz de enseñanza y propaganda en todos los órdenes; un arma política de imponderable eficacia por su naturaleza, su capacidad de proselitismo, su enorme poder mimético y cautivador que invade las facultades imaginativas y sensitivas y mueve la voluntad provocando sentimientos, conductas, actitudes, juicios y criterios de acuerdo con el propósito de los realizadores de las películas; todo ello de forma sutil, amena, atrayente y eficaz $^{97}$

30 Si bien el arte podría acaso ser amoral, el cine ocupa otro lugar por su carácter masivo ${ }^{98}$, pero además argumenta Ortiz que a mayor número de espectadores en una sala hay menor resistencia de ellos a aceptar indiscriminadamente los contenidos que se observan ${ }^{99}$. Ciertamente las películas de Hollywood están bien hechas, son de calidad, técnicamente impecables, aunque muestran su gusto por el dinero y por el éxito, invadiendo la imaginación. La ventaja es que el cine también puede ser un medio original e ingenioso de proporcionar diversión y entretenimiento ${ }^{100}$. Para eso es necesario negociar entre la necesidad del público de distracción y de evasión y proponer simultáneamente lo didáctico, ya que este espectáculo "ejerce una positiva influencia en la vida y costumbres del pueblo, es directamente responsable del progreso espiritual y moral de las gentes y puede contribuir al logro de un tipo más elevado de vida social y de un modo de ser y de pensar más correcto y digno" ${ }^{101}$. También para el Papa el cine es un arma de doble filo que puede ayudar en la labor de la "regeneración moral" 102 lo mismo puede "inducir al bien que [...] inclinar al mal" ${ }^{103}$. Un asunto que molesta particularmente a Ortiz Muñoz es que las historias que cuentan las películas 
penetran en la intimidad de las personas, en sus pecados y caídas. Ciertamente una de las características del cinéfilo es la conducta voyeur, propia de todo espectador, y esto se liga particularmente con el melodrama, pues el género hace gala de mostrar los secretos de su sociedad, en su juego arquetípico entre Bien y Mal, deber y querer, y los problemas humanos relativos a los géneros sexuales y a la diferencia generacional que alude a tabúes existentes en el amor de pareja y de la relación padres- hijos. El melodrama trata problemas insoslayables pero irremisibles que cada generación y todas las culturas han tratado de resolver. El melodrama, además, forma parte de los devaluados body genres (junto con el cine pornográfico y de horror) que provocan manifestaciones físicas y emotivas, para más húmedas como son las lágrimas, difícilmente controlables. Al decir de Ortiz Muñoz el cine penetra:

Por ejemplo, en el secreto de unos amores ilícitos [que] ha invadido la intimidad del hogar, no para enseñarnos las fatales consecuencias de aquellos amores ilícitos, o para descubrirnos el drama familiar, más o menos sublime o vulgar, sino para recrearse en una visión torpe y grosera de desnudeces o atrevimientos lascivos o para interpretar las leyes humanas del instinto como móviles definitivos en una concepción puramente materialista o pagana del amor. ${ }^{104}$

31 Parece molestarle más el "cómo" lo hace que el hecho, y es notable el miedo que muestra a la pérdida de la privacidad en pantalla. Considera que el público español ha aprendido a evitar la "morbosidad", palabra muy gustada por él, y cuando ve escenas "a la americana" se comporta con decoro, porque no le gusta ser testigo de esas "efusivas expansiones" ${ }^{105}$. El modelo al que Ortiz aspira es la austeridad, el buen gusto, cuando el morbo de la violencia y de la sangre típicos del melodrama resultan no sólo vulgares sino perniciosos: "el diablo es tramposo". La pulsión a la escopofilia, a ver, estructura al cine y en el melodrama se explaya una dramatización de los sufrimientos humanos, de los más privados y/o secretos, que permite a los espectadores ver en otros lo que no se confiesan necesariamente en ellos mismos. El aroma del melodrama penetra en esos años de manera notable en España y en los países hispanoamericanos en todas las artes narrativas populares: la literatura de cordel, la radionovela, el teatro, el cine, las canciones, y construye una forma de comprender el mundo. Hereda un estilo que se sistematizó durante la Revolución Francesa, porque, como argumentó en 1976 Peter Brooks, entonces se requiere de un código de valores laico que sostenga ideológica e imaginariamente las nuevas necesidades sociales, un sistema que suplante al código religioso que perdía aceleradamente su papel de legitimador ideológico, de manera que además de construir una estética propone también una ética, otorga valores morales a la vida privada y adapta elespíritu religioso a las nuevas necesidades republicanas y laicas ${ }^{106} \mathrm{y}$ aunque no se modifican ciertos supuestos culturales muy afianzados en las mentalidades, sí se modernizan. Esto no era suficiente para el proyecto de nación que quería construir la Junta. Lo suyo era más radical: la vuelta a los valores de atrás, y aunque el arquetipo básico del melodrama sea la tensión siempre presente entre el Bien vs. Mal cuya resolución normalmente avala las ideas tradicionales, aquí se trata de que esos valores se reconozcan como parte de la doctrina católica.

\section{El sexo, Eva, el deseo .... y la censura}

El mal que transmitía el cine de Hollywood era para ellos el mal por antonomasia. En el Proyecto observamos las medidas concretas de lo que antes Ortiz Muñoz había argumentado en abstracto contra la frivolidad en el sexo y/o el amor carnal, el 
erotismo, las ideas políticas "disolventes", las religiones no católicas y cualquier otra heterodoxia posible. Es mala la violencia manifiesta y también algo más sutil: el llamado "mal gusto" conforma un inventario de lo que se debe evitar para construir la España "verdadera" y que observamos también en los expedientes de las películas, la España contenida, sobria, recatada, austera, y recia. La preocupación más evidente en Ortiz Muñoz es por las películas que muestran el sexo y el erotismo, pues explica que el 95 por 100 tratan el tema del amor, pero "de un amor encendido en sensualidades precoces y en sensualidades plebeyas, propias de mujeres [...] a las que [...] sin reparar en si el objeto de sus conquistas es o no libre, tiene o no responsabilidades afectivas y sociales, puede o no dedicarse a dichos entretenimientos" ${ }^{107}$. Sorprende la mirada en que asocia sin lugar a dudas el mal del amor físico con la actuación femenina: "La inmoralidad de estos amores salta a la vista, y deja sobre el ánimo que los contempla el deje amargo de los valores femeninos que desaparecieron para las prudentes y honradas"108. La mujer aparece como depositaria del pecado y por una vez activa, para procurarlo, de acuerdo a una tradición católica añeja de misoginia, y esta situación afecta a todo aquel que lo mire, por ejemplo respecto a mostrar los besos considera que "puede provocar también en otros jóvenes apasionados el deseo de besuquear y manosear a la novia o a la amiga, y que pudiera ser una de vuestras hermanas o de nuestras hijas" ${ }^{109}$. En esta imagen avasallante de Eva lo que adivinamos es la idea de un enorme poder y la asignación anticipada de una culpa. Cabe hacer notar que el erotismo femenino no se contempla siquiera como posible por este autor, no se le ocurre pensar en los efectos en ellas de desnudeces masculinas, por ejemplo, como tampoco puede imaginar la homosexualidad. En cambio, Ortiz Muñoz se ha puesto a pensar obsesivamente en los deseos masculinos y concluye:

[...] hemos de considerar nuestras peculiares y características reacciones temperamentales ante el instinto sexual [...]. Un español, por temperamento reacciona siempre virilmente ante cualquier motivo sensual. Esta reacción [...] supuesta la naturaleza caída, es, a mi juicio, la natural en el hombre normal y sano.

Declara que ha meditado acerca de :

[...] si sería posible que los españoles llegáramos a un sosiego de nuestra concupiscencia admitiendo y autorizando una mayor libertad de costumbres y más amplitud de criterio en la vida de relación de los dos sexos. Es decir: ¿ Hay medio de conseguir que nuestros jóvenes no sientan la llamada de la sangre, ni se produzca en ellos la excitación venérea, a la vista por ejemplo de una mujer incitante, de un espectáculo procaz, de unas pantorrillas o unas nalgas femeninas al descubierto, ante los motivos, en fin, que normalmente provocan en nosotros la excitación carnal? ${ }^{110}$

Nuestro censor ha pensado si acaso una educación menos pudorosa pudiera modificar esta actitud y concluye que no: "lo nuestro no es un problema de educación o hábito. Es un problema de temperamento" e intentar modificarlo llevaría a "la degeneración de la raza", porque esas reacciones son las normales en un "hombre español normal, un labriego, un trabajador, un hombre sano, en fin" y si no las tiene "o ha de estar ahíto de deleites carnales, o el vicio lo ha reducido ya a la más vil impotencia"111. No hay modo de que se salve: si desea sexualmente porque lo hace, si no desea porque es síntoma de sus excesos. Argumenta de modo cientificista o naturalista que es así por el temperamento sanguíneo de los españoles y que en países fríos de educación "más o menos pagana o materialista" es diferente, pero entra en contradicciones, pues si "un español sano [que] desde un punto de vista puramente natural, reaccionaría como hombre" le parece normal, la otra actitud le parece que "es más animal, más 
deformado, y cuando no concurren circunstancias también temperamentales, es más vicioso" 112 . Ortiz se ha metido al laberinto de la castidad, y considera "generalmente, un mito o una falsedad" ${ }^{133}$, con lo que muchos habrán pensado si acaso Ortiz lo hace extensivo en el voto sacerdotal, y quizás nuestro autor busque una salida cuando afirma que "en la mayoría de los casos se llega a ella [la castidad] después de muchas prevaricaciones". Se refiere al temperamento sexual de los españoles como a una esencia, pero entonces ¿cómo podría modificarse mediante la censura?, ¿qué hacer para "salvaguardar los principios eternos e inconmovibles del orden moral sin menoscabo de aquella prudencia política [...] que ha de tener en cuenta la malicia humana"? y responde: seguir al Catecismo y prohibir todo aquello que produzca "efecto pernicioso" en el espectador normal, que propicie el pecado: "Todo aquello que para un español normal -ni timorato ni vicioso- constituya, objetivamente considerado, motivo de escándalo ha de prohibirse"114. Cuando no lo ilumina su fe redentora la solución puede ser esconder el bulto bajo la alfombra.

\section{Censura e hispanismo en Ortiz Muñoz}

Toda identidad cultural y nacional se forja al construir lo que la distingue de "otro" hipotético, y aquí, como vimos, el "otro" es representado nítidamente por el cine estadounidense. El punto está declarado en la Vigilanti Cura y en Torres Torija, que vimos atrás, pero el Papa considera que cada país debe de tener oficinas de censura con la presencia de un eclesiástico y con redes internacionales de ayuda mutua. Los expertos designados deben de ser personas que conozcan la técnica cinematográfica y al mismo tiempo tengan bien arraigados los principios de la doctrina católica ${ }^{115}$. Ortiz Muñoz considera que sí, que cada país debe hacerlo de acuerdo a su ideología religiosa, política y social y por eso el catolicismo debe pautar a la Península.

Durante la dictadura de Francisco Franco, el hispanismo fue concebido como una cruzada para divulgar la ideología hegemónica del Estado en cuanto a la tradición, el idioma, la religión, el respeto al linaje y a las jerarquías sociales, políticas y religiosas que se consideran esenciales a su cultura y la de las excolonias. El hispanismo conservador se fortaleció durante la dictadura de Primo de Rivera con Ramiro de Maeztu, José Ma. Pemán, Eugenio Vegas, José Calvo Sotelo y otros con ideas católicas, derechistas y monárquicas, que abrevan de Marcelino Menéndez y Pelayo en la observación del catolicismo como esencia nacional ${ }^{116}$, de manera que a las ideas imperiales ya clásicas del hispanismo se suma la de su carácter religioso. Maeztu editó en 1934 Defensa de la hispanidad, en donde considera que "[...] el ejemplo clásico de España no ha de ser meramente un espectáculo en ruinas [...] sino el guión y el modelo del cual han de aprender todos los pueblos de la tierra"117. Haciendo eco a estas posturas en el Epilogo, Francisco Ortiz Muñoz teme la pérdida de:

[...] lo más estimable que poseemos: nuestra fe, nuestras tradiciones, nuestra recia personalidad, nuestro profundo y cristiano sentido de la vida y de las costumbres. Sin esto, ¿qué nos queda que nos distinga y nos haga superiores a aquellos países del mundo que no tienen nuestra misma concepción trascendental y sobrenatural de la vida? ${ }^{118}$

España es un pueblo pobre, sin riqueza material ni bélica:

¿Qué pesamos pues en el concierto de las naciones si se enjuicia nuestro poderío desde un punto de vista puramente material y mecánico? Poseemos, en cambio, ese tesoro inapreciable de nuestra fe, nuestra religión, nuestros principios morales; un 
concepto santo de la familia, del hogar, el culto al honor, a la justicia, a la fidelidad, al deber, a la caballerosidad; el respeto a la dignidad de la mujer, en la que vemos sobre todo a la madre de nuestros hijos; finalmente ese sentido cristiano de la vida y de las costumbres sociales y familiares. Este tesoro, mucho más estimable que todas las riquezas, y que todo el poderío y las fuerzas materiales del mundo hemos de defenderlo rabiosamente, con los dientes y con las uñas, pues en su conservación nos va la propia existencia y categoría como nación, civilizadora de continentes, y la propia salvación como seres humanos que sentimos y profesamos la fe en Jesucristo y en su doctrina. HE DICHO. ${ }^{119}$ acepta diversiones malsanas para sus jóvenes "se encuentra en grave peligro de perder su grandeza y su propio poderío nacional" ${ }^{120}$ y por eso Ortiz considera medular "conservar impolutos nuestro individualismo nacional, nuestra historia, nuestros hechos diferenciales, nuestra tradición, nuestra juventud y nuestra fe" ${ }^{121}$ para lo que es necesario ejercer una "censura inteligente, enérgica, responsable" y fomentar una industria fílmica española ${ }^{122}$.

\section{Blandiendo tijeras}

Para Ortiz Muñoz su obligación es procurar que la enseñanza, la diversión y el arte fílmico estén "al servicio, o cuando menos no en contradicción de nuestros grandes ideales religiosos, políticos, sociales y artísticos" ${ }^{123}$. Para esto hace falta que cada film cubra tres condiciones, que responda adecuadamente a tres peguntas ineludibles: ¿Cuál es la intención al desarrollar un tema, cómo se realiza y cómo se resuelve? La primera debe ser noble y digna, el desarrollo decoroso y pulcro y la resolución ejemplar y aleccionadora ${ }^{124}$, pero el censor debe actuar con prudencia política, "permitir o disimular ciertos males cuya prohibición traería consigo otros mayores" ${ }^{125} \mathrm{y}$ tomar en cuenta el carácter del pueblo español. Ortiz Muñoz observa niveles en el film, la diégesis y la mimesis, aunque no las nombre así, y sabe que a menudo no concuerdan: "si muchos de los argumentos del cine son inmorales, más inmorales son aún las presentaciones, las realizaciones plásticas de aquellos argumentos" ${ }^{126}$, por ejemplo los vestidos parciales o las transparencias "que deja ver las formas femeninas", más mórbidos que el desnudo total ${ }^{127}$, desde gasas que dejan ver senos al "realce provocativo o incitante de aquellas partes del cuerpo que suscitan más directamente el instinto y el apetito sensual", tipos de ropa de dormir o aún de calle que muchas veces son "más incitantes que la desnudez del cuerpo mismo porque dan al tipo un relieve de belleza y de perfección de forma de las que el tipo carece"128, también posturas, gestos y ademanes pueden ser muy sugerentes, para no hablar del gesto procaz o del dicho grosero, y ahí entran los besos apasionados que simbolizan la entrega carnal ${ }^{129}$. No podemos regatearles a los censores el conocimiento de muchas de las entretelas del cine, su saber que cada película es polisémica, que hay formas de contar, discursos que no son evidentes y más allá de la risa que nos provoca hoy en día la censura a los bailes en que no se separan los pies del piso, es claro que la danza de este tipo pierde su calidad gimnástica para recuperar la erótica.

Ortiz Muñoz distingue entre dos tipos de pecado que hay que evitar mostrar: el repelente por sí mismo, como el asesinato, el robo, la crueldad, la mentira, o la hipocresía que son menos peligrosos, y aquellos más atractivos que considera son el principal gancho del cine estadounidense se relacionan con el sexo, el individualismo, 
el heroísmo aparente que esconde actos delictivos, por ejemplo el bandolerismo bienhechor. El primero se rechaza por el espectador en forma instintiva, pero el segundo atrae y "no deben admitirse ciertas argucias de que se valen algunos realizadores cinematográficos para exponer sus temas". Por eso, en la factura de un film:

[...] la extensión dedicada a enaltecer el bien y la virtud debe ser proporcional a la empleada en exponer el error, el mal y el pecado, si no en longitud, por lo menos, en intensidad dramática y emotiva, de forma que el efecto beneficioso supere en todo caso a la impresión producida por la exposición de los hechos reprobables. ${ }^{130}$

41 En casos es importante que si algo malo parece bueno, su réplica sea igual de contundente, pues la ambigüedad no debe engañar al minucioso censor. Puede presentarse el mal, pero siempre debe ser vencido por el bien. Ortiz Muñoz da más importancia al tema sexual que a otros contenidos, pero dice no propugnar para el cine "la ñoñería, la simpleza, la beatería, ni los temas enclenques, blandengues, sin nervio, sin pasión ni emoción", antes bien, explica, hay que tratar temas duros y crudos, pasiones, odios, celos, venganzas, infidelidades, dramas y tragedias de la vida, pues para que una película funcione debe tener "emoción, nervio e interés", ser un "drama intenso y vigoroso" pero siempre humano, ejemplar y aleccionador. Puede tratarse de una anécdota "chispeante, atrevida, punzante, pícara, pero correcta" 131 , y considera que gracias a la eficiencia de la censura la gente ha ido al cine, se ha divertido, se han visto las mejores producciones extranjeras y las películas "se han limpiado del cieno y la obscenidad que las invadía" ${ }^{132}$. Los espectadores han aprendido a funcionar con decoro, porque se han enseñado el "buen gusto" y la conducta adecuada al Régimen. También el Papa considera que aunque el cine tenga límites cuando sea agente de la moralidad gustará a sus públicos y no representará pérdidas ni en el sentido artístico ni en el negocio fílmico ${ }^{133}$.

\section{Para concluir}

En el año 1948 el Sindicato del Espectáculo de Falange organizó el primer Certamen Cinematográfico Hispanoamericano en Madrid, para dirigir las ideas del hispanismo a la actividad cinematográfica de habla española y crear una industria que compitiera con Hollywood. Ese mismo año Ernesto Giménez Caballero escribió un libro titulado Amor a Méjico (a través de su cine) ${ }^{134}$, pues retóricamente se los presentaba siempre como si fueran almas gemelas que compartían una cultura, aunque sus diferencias respecto al cine se manifestaban en la censura que sufrían sus películas ${ }^{135}$. En ese año los vínculos con México y Argentina fueron muy importantes, en aras de formar esa meca cinematográfica para los mercados católicos e hispanohablantes ${ }^{136}$. Las ideas de Ortiz Muñoz significan un catálogo de los principios que habrían de regir ese proyecto fílmico fracasado. Ortiz Muñoz quiso construir el reino de Dios en la tierra, él era un hombre de fe, en el sentido religioso y en el de Oakeshott. Ortiz cree ciegamente en una política estatal, en este caso montada en la religión como su instrumento táctico, mientras que su estrategia es la perfectibilidad del ser humano. La arrogancia y la prepotencia, como las define Bobbio son evidentes en esta empresa, la fe en su actuación corrige la que el cree obra de Dios, la de un hombre malo por naturaleza al que él ayudará a redimir. 
43 Michel Foucault plantea que "[...] el discurso [...] no es simplemente lo que manifiesta (o encubre) el deseo; es también el objeto del deseo" ${ }^{137}$, y está vinculado con el poder, de manera que lo que se prohíbe muestra "[...] aquel poder del que quiere uno adueñarse" ${ }^{138}$, de manera que en lo que prohíbe y elude, alude y convoca. La preocupación por la sexualidad parece en Ortiz Muñoz casi tan fuerte como lo es, muy de otro modo, en Sigmund Freud. ¡Quién lo dijera!

\section{NOTAS}

1. Madrid, Imprenta de Editorial Magisterio español, 1946.

2. Entre 1937 y 1945 el organismo se llama Junta Superior de Censura Cinematográfica, y en este último año Junta de Clasificación y Censura de Películas Cinematográficas, hasta 1963 en que es Junta de Censura y Apreciación de Películas, en 1973 Junta de Ordenación y Apreciación de pelí culas Cinematográficas y en 1974 Junta de Calificación y Apreciación de Películas hasta su suspensión en 1977. En un primer momento depende del Ministerio del Interior, luego de Educaci ón Nacional y más tarde de Información y Turismo.

3. Rosa AÑOVER, La política cinematográfica española. 1939-1945, Madrid. Memoria de Licenciatura. Universidad Complutense de Madrid. Facultad de geografía e Historia. Departamento de Historia Contemporánea, Septiembre de 1982.

4. Román GUBERN y Doménech FONT, Un cine para el cadalso. Cuarenta años de censura cinematográ fica en España, Barcelona, Euros, 1975 (Colección España: Punto y Aparte), p. 208.

5. Los expedientes de censura cinematográfica están en la Sección Junta de Calificación y Apreciación de Películas del Archivo General de la Administración, Sección Cultura, sita en Alcalá de Henares. Abarca el período 1939-1977 y está conformado por 1396 cajas con 50472 expedientes organizados en gruesos tramos cronológicos.

6. ORTIZ, op. cit., p. 7.

7. Teodoro GONZÁLEZ BALLESTEROS, Aspectos jurídicos de la censura cinematográfica en España: con especial referencia al período 1936-1977, Madrid, Universidad Complutense, 1981, p. 352.

8. Uso este término clásico de Louis ALTHUSSER porque precisa el caso que nos ocupa, al llamar así a ciertas instituciones especializadas que sirven a la función represora del Estado desde el plano ideológico. "Ideología y aparatos ideológicos del Estado". En La filosofía como arma de la revolución en Cuadernos de Pasado y Presente, n 4, México, Siglo XXI Editores, 1974, p. 109-110.

9. Román GUBERN y Doménech FONT, op. cit., p. 9.

10. Ibid., p. 18.

11. ORTIZ, op.cit., p.5. La Comisión Nacional de Censura Cinematográfica atendía casos no contemplados por la Junta y de apelación.

12. Ibid., "Normas Generales de Producción", p. 25.

13. Ibid., Apéndice I, "As enforced by the motion Picture Association" Code de [sic] Production Standards, p. 33.

14. Ibid., Art. 9, Cap. I, “Delitos”, Art. 2-9, p. 26.

15. Ibid., Cap. I "Crimes against the Law”, Art. 4, p. 34.

16. Ibid., Cap II, "Sexo", Art. 13-c, p. 27.

17. Ibid., Cap. II, “Sex”, Art. 7, p. 34.

18. Ibid., Cap. IV, “Bailes”, Art. 24, p. 28. 
19. Ibid., Cap. VIII, "Religion”, Art. 1-3, p. 35.

20. Ibid., Cap. VII, “Religión”, Art. 33-38, p. 29.

21. Ibid., Cap. VIII, "Instituciones nacionales", Art. 40, p. 29.

22. Ibid., Cap. VIII, "Repellent subjets", Art. 6, p. 29-30.

23. Ibid., p. 30.

24. Ibid., p.5.

25. Ibid.

26. Ibid.

27. Ibid, p. 30.

28. Ibid., p. 6.

29. Ibid., p. 30.

30. Ibid., p. 6.

31. Ibid.

32. Ibid., p. 15.

33. Ibid., p. 17.

34. Ibid., p. 6.

35. Ibid.

36. Ibid., p. 13.

37. Ibid., Apéndice II, "Carta Encíclica de S.S. el Papa Pío XI acerca de los espectáculos cinematográficos", p. 44.

38. Michel FOUCAULT, El orden del discurso, Lección inaugural pronunciada en el Collège de Francia el 2 de diciembre de 1970, Barcelona, Tusquets Editores, Col Fábula, 1999.

39. ORTIZ, op. cit., p. 6.

40. Ibid

41. Ibid., p. 7.

42. Ibid., p. 6.

43. Ibid., Encíclica, p. 40.

44. Ibid., p. 5.

45. Ibid., p. 17.

46. Secretariado Nacional de la Comisión Episcopal española de Cine, Radio y Televisión. Guía de películas estrenadas. (1954-1959), Madrid, Delegación Eclesiástica Nacional de Cinematografía-Fides Nacional, p. 1060.

47. "Elogio de la templanza". En Norberto BOBBIO, Elogio de la templanza y otros escritos morales, Madrid, Temas de Hoy S.A., 1997, p. 55.

48. Ibid., p. 56.

49. ERASMO, La educación del príncipe cristiano, citado por Bobbio, op. cit., p. 57.

50. Ibid., p. 59.

51. Ibid., p. 61-62.

52. Michael OAKESHOTT, La política de la fe y la política del escepticismo, México, FCE, 1998.

53. Roger BARTRA, Las redes imaginarias del poder político, México, Océano, 1996.

54. Michel FOUCAULT, op. cit.

55. Lo entiendo como un sistema de ideas, imágenes, conceptos, valores que emergen de una sociedad dada para cumplir una función adecuada a los intereses de un determinado grupo social, que se intenta imponer a la sociedad en su conjunto o a grupos de ella para que sea “ dominante", lo que rara vez se logra, produciéndose siempre un campo de tensión.

56. Conjunto de ideas no conscientes ni sistematizadas, emociones, valores, afectos y temores que se traducen en comportamientos, rituales, prácticas y actitudes, aceptaciones y rechazos muchas veces sin una consistencia aparente. No son homogéneas, pese a que así se trataron anteriormente.

57. José ORTEGA Y GASSET, Ideas y creencias, Madrid, Espasa Calpe, 1940 (Ed. Austral). 
58. Michel FOUCAULT, Historia de la sexualidad. I. La voluntad de saber, México/España, Siglo Veintiuno Editores, 1977, p. 116.

59. Antonio GRAMSCI, La formación de los intelectuales, México, Grijalbo, 1977. También de este autor, Cultura y Literatura, Barcelona, Península, 1977, y Obras, México, Juan Pablos, 1975.

60. Pierre BOURDIEU, La distinción. Criterios y bases sociales del gusto, México, Taurus/Aguilar, 2002.

61. Se dice que una cultura se comparte cuando hay palabras y hábitos lingüísticos, tradiciones, comportamientos, ritos, convenciones, gestos, valores, creencias, representaciones e imágenes colectivas que tienen significados comunes y devienen en símbolos. Estamos entonces ante un imaginario compartido.

62. Manuel TUÑÓN DE LARA, "El krausismo y la Institución Libre de Enseñanza: sus diversas proyecciones en la vida cultural española. Giner. Azcárate. Cossío", Medio siglo de cultura española (1885-1936), Madrid, Tecnos, 1970, p. 37.

63. Teresa RODRÍGUEZ DE LECEA, “La Institución Libre de Enseñanza. La escuela de la Institución ", Historia 16, Madrid, año 5, n 49, p. 73.

64. TUÑóN DE LARA, op. cit., p. 46.

65. Ver Donald M. LOWE, Historia de la percepción burguesa, México, FCE (Breviarios, 430), 1986 [1982], p 20.

66. Michel DE CERTEAU, "La magistrature devant la sorcellerie au XVII ${ }^{\mathrm{e}}$ siècle", L'Absent de l'h istoire, Tours, Maison Mame (Sciences Humaines et Ideologies), 1973.

67. ORTIZ, op. cit., Encíclica...., p. 42-43.

68. Ibid., p. 13.

69. Los conceptos que dominan en su propio tiempo son llamados aquí dominantes o hegemón icos, otros parecen adelantarse y abrir nuevos tiempos y/o expectativas, son los emergentes, que no siempre son bien aceptados y otros tienen su sentido del pasado y es por las inercias como se mantienen vigentes. Lo residual no es necesariamente obsoleto, puede ser vivido como válido aunque surja de necesidades sociales previas. Ver en un sentido similar Raymond WILLIAMS, Marxism and Literature, Oxford, Oxford university Press, 1977, p. 121-127.

70. Michel. FOUCAULT, Las palabras y las cosas. Una arqueología de las ciencias humanas, México-Espa ña, Siglo XXI Editores, 1979 [1966], p. 5.

71. Umberto ECCO, Apocalípticos e integrados, México, Lumen y Tusquets Editores, 1995 [1965], p. 51.

72. O sea, de acuerdo con Pierre Bourdieu, un espacio estructurado, relativamente autónomo, con códigos de significación propios, instituciones específicas, jerarquías, normas de funcionamiento y en el cual hay tensiones de índole muy diversa. "Algunas propiedades de los campos”, Sociología y cultura, México, Ed. Grijalbo-Consejo Nacional para la Cultura y las Artes, 1990.

73. ORTIZ, op. cit., Cap. VI, "Vulgaridad”, Art. 32, Proyecto... p. 29.

74. Ibid., Cap. V, "Indumentaria”, Art. 26-31, Proyecto... p. 28.

75. Pierre BOURDIEU, op. cit.

76. Ibid., p. 7-8.

77. Ibid., Encíclica... p. 39.

78. Ibid., p. 24.

79. Ibid., Art. 2-Art. 11, "Otros delitos", Proyecto... p. 26.

80. Román GUBERN, Del bisonte a la realidad virtual. La escena y el laberinto, Barcelona, Anagrama (Colección Argumentos), 1996, p. 45.ORTIZ, op. cit., p. 23.

81. ORTIZ, op. cit., p. 23.

82. Ibid., p. 24.

83. Michel FOUCAULT, El orden del discurso, op. cit., p. 53.

84. Ibid., p.14. 
85. ORTIZ, op. cit., Encíclica..., p. 42.

86. Ibid., p. 10.

87. Ibid., p. 11.

88. Ibid.

89. Ibid., p. 8.

90. Ibid., p. 12.

91. Ibid., p. 17.

92. Ibid., p. 23.

93. Ibid., p. 17.

94. Ibid., p. 8.

95. Ibid., p. 12.

96. Ibid., p. 11.

97. Ibid., p. 12.

98. Ibid., p. 22.

99. Ibid., p. 23.

100. Ibid., p. 12

101. Ibid., p. 21.

102. Ibid., Encíclica..., p. 41.

103. Ibid., p. 40.

104. Ibid., p. 8.

105. Ibid., p. 17.

106. Peter BROOKS, The melodramatic Imagination. Balzac, Henry James. Melodrame and the Mode of Excess, New Haven/Londres, Yale university Press, 1976.

107. ORTIZ, op. cit., p. 8-9.

108. Ibid., p. 9.

109. Ibid., p. 16.

110. Ibid., p. 13.

111. Ibid., p. 13-14.

112. Ibid., p. 14.

113. Ibid.

114. Ibid.

115. Ibid., Encíclica, p. 44-47.

116. Fredrick B. PIKE, Hispanismo, 1898-1936. Spanish Conservatives and Liberals and their Relations with Spanish America, Notre Dame, University of Notre Dame Press, 1971, p. 277.

117. R. DE MAEZTU, Defensa de la hispanidad, Buenos Aires, Poblet, 1941, p. 45.

118. ORTIZ, op. cit., Epilogo..., p. 31.

119. Ibid., p. 31-32.

120. Ibid., p. 42.

121. Ibid., p. 12-13.

122. Ibid., p. 13.

123. Ibid., p. 12.

124. Ibid., p. 18.

125. Ibid., pp 6-7.

126. Ibid., p. 9.

127. Ibid

128. Ibid.

129. Ibid., p. 9-10.

130. Ibid., p. 24.

131. Ibid., p. 18

132. Ibid., p. 17. 
133. Ibid., Encíclica..., p. 41.

134. Ernesto GIMÉNEZ CABALLERO, Amor a Méjico (A través de su cine), Madrid, Seminario de Problemas Hispanoamericanos. 1948, Cuadernos de Monografías, $n^{\circ} 5$.

135. He trabajado el tema en “'Toda la mugre latina': Cuentos de hadas, censura española y cine mexicano en los años cuarenta y cincuenta”. En prensa para actas del VI Congreso Internacional del GRIMH: Image et Imagination, Lyon.

136. He trabajado el tema en "Relaciones de celuloide: El primer Certamen cinematográfico Hispanoamericano. Madrid: 1948". En Clara LIDA (Coord), México y España durante el primer franquismo: 1939-1950. Rupturas formales, relaciones oficiosas, México, El Colegio de México, 2002. "Enamorada (Fernández, 1946) en Madrid: la recepción de una película mexicana en la España franquista”. En Angel MIQUEL, Jesús NIETO SOTELO y Tomás PÉREZ VEJO (Comp.), Imágenes cruzadas. México y España, siglos XIX y XX, Cuernavaca, Universidad Autónoma del Estado de Morelos, 2005. Con re-edición En Javier HERRERA y Cristina MARTÍNEZ-CARAZO (Ed), Hispanismo y cine. Frankfurt-Madrid, VervuetIberoamericana, 2007. También en "Imágenes filmicas de México en la España franquista: la mirada de Ernesto Giménez Caballero". En Entrepasados. Revista de Historia, Año XII. N23, Buenos Aires, 2002.

137. FOUCAULT, El orden del discurso, op. cit., p. 14.

138. Ibid., p. 15.

\section{RESÚMENES}

Francisco Ortiz Muñoz dio en Madrid en 1946 una conferencia y como producto de ella publicó Criterios y normas morales de censura cinematográfica. Conferencia pronunciada en el Salón de Actos del Consejo Superior de Investigaciones Científicas el día 21 de junio de 1946. Eran los años en que la censura estaba ya suficientemente impuesta para tener criterios establecidos, pues ya habían pasado muchas películas bajo la mirada inquisidora de la Junta de Clasificación y Censura de Películas Cinematográficas, pero las normas no eran claras, pues la primera codificación es de abril de 1963. La discrecionalidad de los censores era común, pero este texto representa una primera sistematización que da cuenta de los andamios ideológicos de la política censora tanto como de las medidas que cada vez más se aplicaban rígidamente.

Francisco Ortiz Muñoz a prononcé à Madrid en 1946 une conférence qu'il a ensuite publiée sous le titre Criterios y normas morales de censura cinematográfica. Conferencia pronunciada en el Salón de Actos del Consejo Superior de Investigaciones Científicas el día 21 de junio de 1946. À cette époque, la censure était déjà bien en place et ses critères établis, car de nombreux films étaient déjà passés devant l'œil inquisiteur de la Junta de Clasificación y Censura de Películas Cinematográficas ; mais, pour autant, ses normes n'étaient pas vraiment claires, car la première codification de la censure à proprement parler date du mois d'avril 1963. L'arbitraire des censeurs était courant, mais ce texte représente une première tentative de systématisation qui rend compte des attentes idéologiques qui sous-tendent cette politique de censure, ainsi que des mesures concrètes qui en découlaient, et dont l'application était de plus en plus rigide. 
ÍNDICE

Palabras claves: censura española, cine español, Ortiz Muñoz (Francisco), junta de clasificación y censura de películas cinematográficas

\section{AUTOR}

JULIA TUÑÓN

DEH-INAH, México 